\title{
Avifaunal Diversity and Abundance at Kammalakkulama Tank in Mihintale, Sri Lanka
}

\author{
H.K.S. De Zoysa* ${ }^{*}$ T.V. Sundarabarathy \\ Department of Biological Sciences, Rajarata University, Sri Lanka \\ *dezoysahks@yahoo.com
}

\begin{abstract}
Most of the studies related to avifaunal diversity have been focused to the wet zone of Sri Lanka and there are few recorded studies on dry zone freshwater bodies. The objective of this study was to evaluate diversity and abundance of avifaunal species around Kammalakkulama tank. The study was carried out from April to December 2013 and the field survey was conducted twice per week, covering the first intermonsoon, the north-east monsoon and the drought period in the dry zone. Point count and line transect methods were used to count aquatic birds and forest birds respectively. A total of 71 species of both 28 aquatic (39\%) and 43 forest $(61 \%)$ belonging to 58 genera and 41 families including three endemic species, i.e., Sri Lankan Jungle Fowl (Gallus lafayetii), Crimson-fronted Barbet (Megalaima rubricapillus) and Pompadour Green-pigeon (Treron pompadora). Asian Paradise-flycatcher (Terpsiphone paradise), Grey Drongo (Dicrurus leucophaeus) and Whiskered Tern (Chlidonias hybrida)) were the recorded migrant species. Shannon Weiner Diversity index $\left(\mathrm{H}^{\prime}\right)$ of aquatic birds in the morning and the evening was 1.74 and 1.45 respectively. The $\mathrm{H}^{\prime}$ index for forest birds in the morning and the evening was 1.75 and 1.33 respectively. Simpson Index (D) of aquatic birds in the morning and the evening was 0.27 and 0.40 respectively whereas the $\mathrm{D}$ index for forest birds was 0.08 in the morning and 0.25 in the evening. Margalef's Diversity Index $\left(\mathrm{D}_{\mathrm{mg}}\right)$ of aquatic birds in the morning was 3.62 and in the evening it was 3.55. The $\mathrm{D}_{\mathrm{mg}}$ index was 5.51 and 3.31 for forest birds in the morning and in the evening respectively. Pielou's J (Evenness) $\left(\mathrm{E}_{\mathrm{H}}\right)$ of aquatic birds in the morning and in the evening was 0.54 and 0.45 respectively. This $\mathrm{E}_{\mathrm{H}}$ index for forest birds was 0.50 and 0.45 in the morning and in the evening respectively. This study clearly reveled that both forest and aquatic birds can be seen in the morning than in the evening which may be the best time for bird watching and study purposes.
\end{abstract}

Keywords: Forest birds, Aquatic birds, Dry zone, Diversity indices, Sri Lanka 